\title{
The Role of Narrative Fiction and Semi-Fiction in Organizational Studies
}

\author{
Gail Whiteman and Nelson Phillips
}

\begin{tabular}{|l|l|}
\hline \multicolumn{2}{|l|}{ ERIM REPORT SERIES RESEARCH IN MANAGEMENT } \\
\hline ERIM Report Series reference number & ERS-2006-079-ORG \\
\hline Publication & December 2006 \\
\hline Number of pages & 29 \\
\hline Persistent paper URL & \\
\hline Email address corresponding author & gwhiteman@rsm.nl \\
\hline Address & Erasmus Research Institute of Management (ERIM) \\
& RSM Erasmus University / Erasmus School of Economics \\
& Erasmus Universiteit Rotterdam \\
& P.O.Box 1738 \\
& 3000 DR Rotterdam, The Netherlands \\
& Phone: + 31 10 408 1182 \\
& Fax: + 31104089640 \\
& Email: info@erim.eur.nl \\
& Internet: www.erim.eur.nl \\
\hline
\end{tabular}

Bibliographic data and classifications of all the ERIM reports are also available on the ERIM website: www.erim.eur.nl 


\section{ERASMUS RESEARCH INSTITUTE OF MANAGEMENT}

\section{REPORT SERIES}

\section{RESEARCH IN MANAGEMENT}

\begin{tabular}{|l|l|}
\hline \multicolumn{2}{|l|}{ ABSTRACT AND KEYWORDS } \\
\hline Abstract & $\begin{array}{l}\text { In this chapter, we discuss the use of narrative fiction and semi-fiction in organizational research } \\
\text { and explore the strengths and weaknesses of these alternative approaches. We begin with an } \\
\text { introduction reviewing the existing literature and clarifying what we mean by fiction and semi- } \\
\text { fiction. We then present and discuss examples of fiction and semi-fiction focusing on how these } \\
\text { approaches can be used in organizational research. We argue that fiction is more useful as a } \\
\text { source of data and as a way of representing theory to an audience. Semi-fiction, on the other } \\
\text { hand, provides a novel approach to the production and representation of theory. In both cases, } \\
\text { researchers face a number of challenges, but also gain access to new and powerful techniques } \\
\text { for developing insights into organizational topics. }\end{array}$ \\
\hline Free Keywords & \begin{tabular}{l} 
Narrative fiction, Semi-fiction, Organizational studies \\
\hline Availability
\end{tabular} \\
$\begin{array}{l}\text { The ERIM Report Series is distributed through the following platforms: } \\
\text { Academic Repository at Erasmus University (DEAR), DEAR ERIM Series Portal } \\
\text { Social Science Research Network (SSRN), SSRN ERIM Series Webpage } \\
\text { Research Papers in Economics (REPEC), REPEC ERIM Series Webpage }\end{array}$ \\
\hline Classifications & $\begin{array}{l}\text { The electronic versions of the papers in the ERIM report Series contain bibliographic metadata } \\
\text { by the following classification systems: } \\
\text { Library of Congress Classification, (LCC) LCC Webpage } \\
\text { Journal of Economic Literature, (JEL), JEL Webpage } \\
\text { ACM Computing Classification System CCS Webpage } \\
\text { Inspec Classification scheme (ICS), ICS Webpage }\end{array}$ \\
\hline
\end{tabular}




\title{
Running head: FICTION AND SEMI-FICTION
}

The Role of Narrative Fiction and Semi-Fiction in Organizational Studies

\author{
Gail Whiteman \\ RSM Erasmus University \\ Burg Oudlaan 50 \\ 3062 PA Rotterdam \\ The Netherlands \\ Phone: +31 (0)10 4081515 \\ Fax: +31 (0)10 4089012 \\ E-mail: gwhiteman@rsm.nl \\ Nelson Phillips \\ Tanaka Business School \\ Imperial College London \\ South Kensington Campus \\ London SW7 2AZ \\ E-mail: n.phillips@imperial.ac.uk
}

Draft Chapter for the Sage Handbook of New \& Emerging Approaches to Management \& Organization (provisional title) Edited by David Barry \& Hans Hansen. 


\section{The Role of Narrative Fiction and Semi-Fiction in Organization Studies}

In this chapter, we discuss the use of narrative fiction and semi-fiction in organizational research and explore the strengths and weaknesses of these alternative approaches. We begin with an introduction reviewing the existing literature and clarifying what we mean by fiction and semi-fiction. We then present and discuss examples of fiction and semi-fiction focusing on how these approaches can be used in organizational research. We argue that fiction is more useful as a source of data and as a way of representing theory to an audience. Semi-fiction, on the other hand, provides a novel approach to the production and representation of theory. In both cases, researchers face a number of challenges, but also gain access to new and powerful techniques for developing insights into organizational topics. 


\section{Introduction}

Organizational scholars are increasingly exploring the usefulness and validity of storytelling and creative narrative in organizational research (e.g., Barry, 1996; Boje, Fitgibbons, \& Steingard, 1996; Czarniawska, 1998, Czarniawska-Joerges \& Guillet de Monthoux, 1994; Knights \& Willmott, 1999; Phillips, 1995; Taylor, 2000; Whiteman, 2004). Phillips (1995), for example, encourages us to use novels, stories, plays, songs, poems and films as legitimate objects for study and as vehicles to convey valuable organizational knowledge that has the potential to enrich our field. To some degree, these calls have been heeded and the use of narrative fiction in teaching (e.g. CzarniawskaJoerges \& Guillet de Monthoux, 1994) and writing (e.g., De Cock, 2000) about organizations has become increasingly commonplace and accepted. While less common, narrative fiction as a focus of study has also become less of a rarity, with several different forms of fiction now appearing as data in the literature (e.g., Parker, Higgins, Lightfoot \& Smith, 1999; Phillips \& Zyglidopoulos, 1999).

At the same time, the use of fictional accounts created by researchers remains highly unusual in management studies, although there are important exceptions (e.g., Hansen et al. 2006; Jermier, 1985; Taylor, 2000). The status of these fictional accounts of organizational life remains unclear and publication is often difficult ${ }^{1}$. The use of semifictional, self-authored accounts is even rarer although recent work by Whiteman (2004) suggests that such genres may be particularly provocative for telling ethnographic tales from the field (van Maanen, 1988).

\footnotetext{
${ }^{1}$ See Hansen et al, 2006 for a useful description of some reactions that might be expected to a narrative fiction submitted to a journal.
} 
In this chapter, we contribute to the ongoing discussion of the potential of fiction and semi-fiction by bringing together existing arguments regarding their use, extending these arguments based on our own experiences, and providing examples of their use. In doing so, we make three important contributions. First, we provide a practical introduction and broad review of the literature and bring together discussions of fiction and semi-fiction, which have tended to remain fragmented and disparate. Second, we compare their respective strengths and weaknesses as approaches to the study of organizational phenomenon. While fiction and semi-fiction are similar methods, they have quite different strengths and are useful in very different ways. Finally, we add to existing arguments for the usefulness of fiction and semi-fiction by arguing for the complementarity of the two methods. While both approaches highlight the potential of narrative fiction, they also point to very different opportunities for contributing to organization and management studies.

We begin with an introduction to the existing philosophical discussions around fiction and semi-fiction, define both terms, as well as revisit some of the organizational literature that discusses or uses fiction or semi-fiction. We then discuss some of the ways that fiction and semi-fiction can be used in organizational research focusing on their distinct roles. We conclude with a discussion of future directions for the development of these methods as approaches to the study of organizations.

\section{“Isn't it all just fiction anyway?”}

When one begins to explore the relevant literature, one quickly finds that the division between fiction and non-fiction is no longer fixed. The battle for some sort of strict boundary between truth and fiction has long been lost. While "fantasy", "truth”, 
"reality”, and "fiction” as terms may carry societal meaning, they do not carry any kind of “objective” status (e.g., Rorty, 1991). Nevertheless, it is clear that this boundary exists in practice and we need to be keenly aware of the societal conventions that shape the usages of these terms in organization studies.

\section{Defining Narrative Fiction}

So what is fiction? From a literary theory perspective, "the author of fiction invites the reader to engage in a kind of make-believe” (Currie, 1985: 386). Furthermore, fiction is a linguistic convention in a double sense (Park, 1982: 417-418):

It is linguistic because it is a convention about language; it is also linguistic because it is a convention concerning a way in which a language in a linguistic product is used. The convention consists in stating that words and sentences in a linguistic product should not be taken as referring to any real things, events, facts, and situations, that is, to the real world. To call Madame Bovary and Alice in Wonderland 'fiction' is to indicate that the words and sentences in these linguistic products are not used to refer to the real world. If we immediately recognize Alice in Wonderland as a fiction that is because the linguistic product indicates itself that what is talked about in it is not real. Fiction is then a linguistic convention about reference. The convention says that the language in a fiction means what it means without its real referent.

Non-fiction, by default, invites the reader to believe in the 'reality' of the referent of the written text - that is, something exists that is not fantasy. The convention of nonfiction is that it refers to something that is not fantasy, but instead something that is 'real'. 
The hybrid form - semi-fiction - offers a potential way through this interpretive maze and contains characteristics of both fiction and non-fiction. In semi-fiction, the author is making direct claims about its reference to 'reality' and yet at the same time, asking the reader to indulge in make-believe. That is, empirical content is presented in a partial (or total) make-believe form for dramatic communicative effect.

For the purposes of this chapter, we will use the broad term "narrative" to describe texts that tell a story. In some cases, the authors may describe such a text as fiction, as non-fiction, or as semi-fiction, depending upon how they wish readers to engage with the text. While one can argue that a 'Rose is a rose is a rose is a rose' (Stein, 1922) - that "it's all just fiction anyway" - we argue that by adopting different textual strategies organizational scholars shape organizational knowledge in different ways. Thus, the relationship between organizational studies and narrative is complex and ambiguous and it is made more ambiguous in that narrative appears in organization studies in several different ways.

For example, Czarniawska (1998: 13-14) suggests that "Narrative enters organizational studies in at least four forms: organizational research that is written in a storylike fashion ('tales from the field,' to paraphrase van Maanen, 1988); organizational research that collects organizational stories (tales of the field); organizational research that conceptualizes organizational life as storymaking and organizational theory as story reading (interpretive approaches); and as a disciplinary reflection that takes the form of literary critique.”

It is interesting to note that there are two different sorts of stories included in Czarniawska's list. On the one hand, there are stories that are produced by organizational 
members themselves and that are then collected together and studied; on the other hand, there are stories written by others (either fiction authors or organizational researchers) that are used in organizational research in some way. The types of stories we are interested in here are of the latter variety; we are interested in the potential use of narrative fiction and semi-fiction as either data or method. That is, we are interested in stories as potential sources of data that can be analyzed to better understand organizational life or as ways of presenting our research results and reflections on organizational life to others.

\section{Narrative Fiction in Organization Studies}

The idea of using fiction as data or method has a relatively brief history in organizational studies. At the same time, as we argued above, a growing body of literature attests to the interest in these innovative approaches. As Whiteman (2004: 3) argues, stories are “a creative means for meaning making and privilege contextualized information and personalized expression”. Nevertheless, using narrative stories in this way lies clearly outside of the mainstream and researchers adopting these approaches face considerable barriers to publication.

The reason for the continued existence of these barriers is somewhat unclear. As Czarniawska (1998: 5) notes: “there are no structural differences between fictional and factional narratives, and their respective attraction is not determined by their claim to be fact or fiction.” Entrenched social conventions are likely the causes of such separation within organizational studies (Phillips, 1995). At the crux of the issue is the conventional status and role of organizational 'data'. Stablein (1996) acknowledges that "[a]ll data are representations” and that “[a]s representations, data imply things that are represented, and 
a process of representing” (p.511). While there has been considerable debate both about the 'reality’ of “The 'Thing' Represented” by data and regarding the representational process, Stablein argues organizational data should - at the very least - be related to the 'empirical world.' But the question remains, how can we do this? We suggest that using the creative techniques of representation without abandoning data in organizational research holds innovative promise. Yet such approaches may face considerable resistance.

Weick (1979; 1995) argues that the standard ways of doing and knowing in an organization (or organizing entity such as academia) tend to follow deeply held schematic approaches to sense-making and that as groups become attached to certain schemas, they actively reinforce the validity of traditional approaches even when this cycle may unduly restrict new ways of knowing. Thus, innovation in sense-making can suffer, and perhaps suffocate, from the very ivory tower which seeks to study and create 'new' knowledge. Other disciplines such as anthropology have also struggled with these issues. For example, Clifford and Marcus argue that "our sharp separation of form from content and our fetishizing of form - was, and is, contestable. It is a bias that may well be implicit in modernist ‘textualism”” (Clifford and Marcus 1986, 21).

Encouragingly, organizational scholars have begun to collapse these artificial boundaries (March; 2006; Phillips, 1995; Whiteman, 2004), and there is a growing stream of research on the process of 'organizational storytelling'. Nevertheless, as organizational scholars, we remain decidedly passive with respect to our own narrative 'play.' While we may be free to study fiction (e.g., March 2006; Phillips \& Zyglidopoulos, 1999), organizational scholars rarely create it and even more rarely do 
they mix fact and fiction together into a bricolage of research findings, without carefully footnoting the differences (see Czarniawska, 1998: 63, Footnote 2). We remain, resolutely, a collection of serious 'non-fictional' authors.

Yet cognitive processing - the ability to understand, think and reflect about phenomenon - is not restricted to the realm of 'non-fiction.' For instance, Bruner (1986) differentiates between two modes of cognitive processing: the logico-scientific mode, and the imaginative-narrative mode. Historically, organizational research favors the logicoscientific approach. Journal articles commonly utilize a neutral, objective tone to produce authorial omnipotence (Jeffcut, 1994) and to demonstrate 'plausibility' (Golden-Locke \& Biddle, 1993). Editorial preferences for rational academic discourse (Jeffcut, 1994) reinforce our emphasis on logico-scientific approaches to scientific sense-making. In contrast, textual strategies which do not conform to established rhetorical patterns provoke the audience to re-examine their beliefs and suppositions about the world and the meaning of research. Imaginative-narrative texts - such as those presented by Jermier (1985) or more recently by Hansen et al. (2006), Taylor (2000) and Whiteman (2004) are examples of what Golden-Locke \& Biddle (1993) call the ‘criticality’ dimension of convincing narrative texts.

In this article, we focus on the imaginative-narrative approach to cognitive processing and argue for the use of fiction and semi-fiction in organizational research. While our argumentation style (clearly thus far) follows a logico-scientific approach, we do so in an ironic attempt to argue ourselves (and our colleagues) out of a schematic academic box. The illuminating role of fiction and the subversive role of semi-fiction in organization studies are discussed in the following sections. 


\section{The Illuminating Role of Fiction in Organization Studies}

The use of narrative fiction has a very long history in social science. Harriet Martineau, for example, was an early proponent of using fiction to teach (O’Donnell, 1989). She began writing her Illustrations of Political Economy in 1832 and wrote a total of 18 volumes of fictional stories based on the belief that "the best way to teach was through stories that gripped the reader’s imagination” (O’Donnell, 1989: 315). Fiction has also often been used widely in social science to add color and life to academic writing with many authors drawing on novels, short stories, plays and movies to emphasize points and set the stage for more rigorous academic writing. Wittgenstein, for example, drew on detective stories in his lectures on sense data and private experience in 1935 (De Cock, 2000).

In organization studies, the use of fiction in teaching is also well accepted (although without quite the same extended history as in economics!). For example, Czarniawska-Joerges \& Guillet de Monthoux (1994: 1) in their book on the topic put it succinctly: "The purpose of this book is to show how good novels can educate better managers”. They then go on to explain why novels are not cases and how they transmit “tacit knowledge” and present a level of complexity beyond any case which engages and challenges the reader. Similarly, in their article arguing for the use of fiction in teaching business ethics, Kennedy and Lawton (1992) state their case eloquently:

We undergo an arousal of suspense concerning the nature of that resolution and its ultimate meaning for us. We also take on various roles vicariously through our reading that allow us, through imaginative enactment, to know things otherwise beyond our understanding. This high level of 
involvement, vicarious role-taking, suspense, conflict, and resolution lead us to new levels of knowing that are both affective and cognitive.

These arguments, and this use of fiction, is well accepted in management teaching with many narrative fictions used in many different classes, suggestions for the use of fiction provided by the authors of textbooks, and various websites and listserv discussions focused on the exchange of suggestions and experiences.

Similarly, the role of narrative fiction as a device in academic articles is also well accepted. A carefully chosen quote from a well-known book adds life and interest to academic articles. Phillips (1995: 637) calls this "fiction as ambiance" and argues that "if we can evoke feeling and images appropriate to the discussion, we can effectively clarify and frame an otherwise dry academic piece”. The qualities that make great works of fiction so impactful - their invocation of an alternative reality, the colourfulness of their language, the immediacy of the images they create - are all things that academic writing generally lacks. They are, in fact, all things that academic writing by convention avoids. The use of narrative fiction therefore provides a useful and engaging contrast to academic writing.

But while these two uses of fiction are well accepted in the social sciences generally, and in organization studies in particular, there are two other uses that are much less well established. First, there are an increasing number of researchers who are treating fictional accounts of organizational life as data. As De Cock (2000: 589), for example, argues "there is an emerging discourse which explodes the myth that reading novels and enhancing our understanding of organizations are mutually exclusive activities”. For some of these writers, fiction is seen as something that supports and furthers the 
traditional work of organizational scholars; for others, it is much more than just a supplement to what we have been doing: "Rather than asking what science fiction can do for organization studies, we want to see what it might do to organization studies” (Parker, Higgins, Lightfoot, \& Smith, 1999: 580).

Narrative fiction thus provides a way to see beyond the world of what has happened into a world that is plausible but goes beyond what we see in our everyday world. In doing so, the discursive practices of narrative fiction challenge us to think differently and perhaps deeper about organizations and management (March, 2006). A recent example of this is given by March who uses "one of the better known poems by William Butler Yeats, Easter 1916, ${ }^{2}$ as an illustration of the proposition that poetry is a natural medium for expressing and contemplating doubt, paradox, and contradiction --features of life, well-known to experienced managers, but normally banished, perhaps with reason, from the public language of management” (p. 70).

Whether one adopts the more or less radical view of the role of fiction as data, what is inescapable is that the use of narrative fiction as data significantly challenges many of the methodological and epistemological principles and assumptions underlying organization studies. The status of the resulting papers is ambiguous and publication is often difficult as reviewers and editors find it impossible to evaluate the contribution and rigor of this kind of work.

An example of this sort of work is Phillips and Zyglidopoulos’ (1999) study of Asimov's Foundation trilogy. They describe their method as follows:

2 William Butler Yeats, “Easter 1916”, pp. 287-289 in A. Norman Jeffares, ed., Yeats’s Poems. London: Macmillan, 1996. 
[O]ur general approach is to treat works of narrative fiction as intensive qualitative case studies. Structured analysis of these ‘thick descriptions' of imaginary worlds allows us to explore issues and ask questions in a different way than is possible using more traditional sources of data. (Phillips \& Zyglidopoulos, 1999: 593)

Let’s look at an illustrative example. Box 1 provides an excerpt from Small World, a novel written by David Lodge. In the excerpt, the character Persse is attending an academic conference held at a regional university in the UK. The session he is attending is being held in a lecture theatre at the university and Professor Swallow is presenting. The short excerpt encompasses a particular experience of conference attendance in a vivid way. It is also, it is worth noting, used by us in just the way we talked about in the previous paragraphs - as a device to add interest to our paper.

----- Insert Box 1 about here ------

But more than that, we suggest that this fiction could be used by organizational scholars as data. If we adopt Phillips \& Zyglidopoulos's method in the preceding example, we are free to treat fictional text like David Lodge's novel Small World as a “intensive case study" of an academic conference. By doing so, we could use this text to develop theoretical insight on the back-stage culture (Goffman, 1959) of conference attendance, including the role of academic boredom in organizational knowledge creation.

In fact, David Lodge’s description of a conference looks quite similar to ethnographic writing in organization such as the work of Rosen $(1988 ; 1985)$ and we 
could carry out very similar analysis to uncover the social dynamics that characterize this account of a conference. It may be fictional, yet few who have attended an academic conference would fail to see much that is familiar in this account. It is precisely this ring of truth, growing out of the keen eye and active imagination of a talented writer, that gives this account academic value.

The final role that narrative fiction fulfills in organization studies is much less common and much more radical. It is also the role where narrative has the most potential to contribute to organization studies. This final role is where organization studies researchers use the practices of narrative fiction in order to produce texts that present theoretical insight about organizational phenomena. As Phillips (1995: 641) argues, "[u]sed in this way, fiction provides a way to test the validity of theory". Fiction allows a complex and nuanced presentation of theory that draws in the reader without the closure and oversimplification of more traditional theory.

Examples of this are quite rare however. Jermier (1985) provides one of the better known examples. In his article he draws on H.G. Wells short story When the Sleeper Wakes to contrast different versions of critical theory. Jermier shows first the world as it appears in one theoretical perspective and then tells the same story again but from the perspective of an alternative theoretical frame. The use of narrative fiction provides an excellent way to contrast the two theories and challenge the reader to choose which one rings more true. Recent work by Hansen et al. (2006) also demonstrates the value of collective narrative improvisation by four authors, a fictional revolving story construction that resulted in emergent theorizing about their topic of organizational storytelling. 
Yet, while there are a small number of examples of fiction as method, the approach remains very rare. The reasons for this are threefold. First, writing good fiction is extremely difficult and far from the training and background of most researchers. Second, the barriers of the peer review system are significant for this sort of work. The system rewards conservatism and adherence to the standard practices of representation for academic articles. This obviously creates serious barriers to the publication of fiction in academic journals. Finally, and perhaps most importantly, the methodological tools to produce this sort of work remain underdeveloped. While there are a few examples of this use of fiction in organization studies, the methodological underpinnings remain undiscussed, leaving authors to "go it alone".

One interesting recent development has important implications for this last issue. It is the development of semi-fiction as a methodology in organization studies. As we discussed above, semi-fiction refers to both a method of research and a particular kind of text. In the next section we discuss the philosophy and practical considerations of semifiction as a method. We believe that semi-fiction provides the necessary theoretical foundation and practical direction to allow much more progress in exploring the potential of narrative fiction as a method in organizational studies.

\section{The Subversive Role of Semi-Fiction in Organization Studies}

Agar (1990: 74) offers this definition of semi-fiction: "when fiction[al] form is laid over a ‘fact-oriented' research process.” Semi-fictional narrative (also known as 'faction' or creative non-fiction) results when creative license is taken with the representational form of empirical data. But why put the two types of texts - fiction and non-fiction - together? We argue that semi-fictional narrative can expand the potential 
meaning of organizational research because "they provide a space for the reader to enter the story and vicariously experience the events portrayed...[and] as fictions they are tremendously flexible” (Phillips, 1995: 671). The factual dimension of semi-fictional narrative helps ground textual messages and encourages readers to gain a greater understanding of a variety of 'serious' topics for organization studies. The fictional dimension can increase reader response and help challenge pre-existing assumptions in a creative and subversive way ${ }^{3}$. As such, semi-fictive works may be particularly good at embodying the 'criticality' dimension of convincing texts (Golden-Biddle \& Locke, 1993).

Semi-fictional narratives can have a useful and unique place within organizational research precisely because they combine the standard format of both non-fiction and fiction in order to provoke readers to re-examine their beliefs and assumptions about research and the world (Whiteman, 2004). This approach is not without a history. For instance, in 1933, the American writer, Gertrude Stein, broke through a linguistic barrier and wrote her own fictive autobiography entitled The Autobiography of Alice B. Toklas. In this book, she ostensibly describes her real-life partner Alice’s 'real' memories of Stein and other modernists in Paris of the 1920s. At the same time, the paradox between the title and the author give us clues that this may indeed not be non-fiction after all. At the same time, the use of 'real-life' characters in 'real-life' settings gives us clues that this may not be fiction after all. As a hybrid form of fiction and non-fiction, the work has

\footnotetext{
${ }^{3}$ We define subversion as an activity which especially intends to overthrow or undermine an established schematic approach.
} 
added impact. At the very least in underscoring how language can both imprison and open our minds to new interpretive possibilities. ${ }^{4}$

As a methodological approach, creative non-fiction emerged most concretely from the field of journalism during the 1960s and 1970s. New Journalism (e.g. Wolfe, 1973; Mailer, 1979; Capote, 1965) allows the journalist to place facts in fictional form. New Journalism

“contain[s] strong elements of reportage, which is the anchor and foundation of the highest quality of journalism and of creative nonfiction. The word "creative" refers to the unique and subjective focus, concept, context and point of view in which the information is presented and defined, which may be partially obtained through the writers own voice, as in a personal essay” (Gutkind, n.d.).

A journalist uses this approach in order to "convey the immediacy of experience and give it coherence and significance” (Agar 1995, p. 116), a textual quality that neither technical non-fiction nor creative fiction alone can usually convey. Creative non-fiction typically makes use of some of the following fictional techniques (see Table 1):

----- Insert Table 1 about here -----

A semi-fictive approach to research may have additional benefits for academic theorizing since this approach helps to reframe data and representational process through discursive play. Play has been shown to increase organizational creativity and innovation (Dodgson, Gann \& Salter, 2005). With semi-fiction, we suggest that authors may actively

\footnotetext{
${ }^{4}$ Stein's publication of Alice B. Toklas also made people like Matisse (and other modernists) publicly denounce it in the Parisian Review despite the fact that it arguably contained the same subversive elements as their paintings (see, Winterson, 1995).
} 
try to identify empirical moments that captured, sometimes in a surprising way, interesting aspects of the organizing form under study. The 'strategy of inquiry' (Denzin \& Lincoln, 1994) can also focus particular attention on empirical experiences that seem out of context, surprising and/or humorous - a recognizable focal technique of ethnographic work (Hammersley \& Atkinson, 1998). Semi-fictive narrative may thus help us broaden our understanding of empirical phenomenon by bringing in provocative creative elements to trigger innovative sense-making of empirical data by authors (and readers). "[B]y re-moulding the reality we assume to be objective, art releases to us, realities otherwise hidden...” (Winterson, 1995: 58). In particular we note the value of semi-fictive collage, where meaning builds with the layers of empirical data and narrative imagination which differs from a more linear style of rational composition.

In addition to provoking more creative empirical reflection, semi-fictive approaches to research may have the ability to convey additional (and different) meanings due the choice of the semi-fictional medium which can conveys its own message(s) (McLuhan, 1967). Semi-fictional narrative has the potential to increase reader empathy because it relies upon emotional and intellectual intersubjectivity (Carrithers, 1990) created in part because of the purposive combination of facts and fiction (Whiteman, 2004). The resulting ambiguities may invite greater reader response (March, 2006; Richardson, 1994).

Box 2 provides an illustrative excerpt of semi-fiction in organization studies. The excerpt is drawn from Whiteman's (2004) paper presenting the results of her dissertation research investigating Traditional Environmental Knowledge among aboriginal Canadians. Rather than present the results of her field research in a traditional format, 
Whiteman uses semi-fictional methods to present the results in the form of a fictionalized narrative about a doctoral student defending her thesis research in front of a committee of more or less sympathetic academics. The device of semi-fiction allows Whiteman to include dissenting voices and, through a sort of magic realism, include the odd intrusion by the natural world that her character Pip is trying so hard to convey to her committee.

--------Insert Box 2 about here -----

As Whiteman's work so clearly shows, content can be enriched by the choice of form. While some meanings are adequately conveyed through logico-scientific approaches to communication, others are more deeply embedded in sensory and emotional understandings. Such meanings may require alternative frameworks for expression which no longer marginalize emotions, humour, values and imagination, and yet do not detach completely from empirical experience.

Despite the positive elements of the subversive quality of semi-fictional narrative, we acknowledge the potential difficulties in evaluating the use of semi-fiction in terms of academic validity. Indeed, concern over credibility is the primary issue raised against the legitimacy of creative non-fiction within journalism (Agar, 1990). Agar (1990) suggests that the route forward lies in a simultaneous discussion - and explication - of the research process itself. That is, a careful discussion of methodology and representative motivation are required. This underscores the importance of an author clearly outlining their own textual guidelines for representation alongside a discussion of the research process (ie., how data was gathered, analyzed, etc.). Agar (1990) stresses the need for indepth immersion in the phenomenon under study in order to develop a 'factual' or deep 
experiential understanding of the empirical data. Semi-fiction thus may work well as a qualitative method for exploring empirical reality and pulling together fragments from fieldwork. And it is in this sense that we describe it as a method of data analysis. It is much more than just a way of presenting data, it is a way of working through the data collected by the researcher and developing deep theoretical understandings.

In developing a semi-fictional narrative, the researcher develops a theory of the social context within which the narrative is set. Thus, semi-fictional work has particular relevance for creatively representing qualitative research, especially with ethnographic research (Whiteman, 2004). However, we believe that a semi-fictive text remains somewhat different from an 'impressionistic tale’ from ethnography (van Maanen, 1988) in that it takes imaginative and fictive license with form, while an impressionistic tale remains less open to elements of 'make-believe.' In a work of semi-fiction there is no need to be bound by what was seen and heard. What is important is to weave together fragments of social 'data' with the creative licence to make the theoretical insights of the researcher vivid and easily available to the reader.

Non-academic writers like Margaret Atwood agree with the need to clearly outline (for themselves at least) their own textual guide when they write creative historical fiction which becomes similar to semi-fiction (e.g., Alias Grace): "to be fair, I had to represent all points of view. I devised the following set of guidelines for myself: when there was a solid fact, I could not alter it...Also, every major element in the book had to be suggested by something in the writing about Grace and her times, however dubious such writing might be; but, in the parts left unexplained - the gaps left unfilled I was free to invent” (1998). 
From our own experience, we have found that a semi-fictional approach to research requires a strong empirical focus, and builds upon concrete data and experience (Stablein, 1996). While semi-fictional text can emerge in a directed way, we also highlight the importance of random aesthetic moments. We suggest that sometimes $e$ semi-fiction may not follow a purposive outline and rather, text which begins to write itself may add value. Nevertheless, authorial motives remain academic in nature - to capture and reflect upon organizing forms and to engage reader in this playful yet potentially penetrating activity. We discuss this in more detail below.

\section{Summing Up: Semi-fiction meets David Lodge}

The purpose of this chapter is to bring together existing thinking and practice on the use of narrative fiction in organization studies. This topic is one that is of increasing importance and interest among organizational scholars but remains at a very early stage. Consequently, we present both a theoretical and practical discussion of this issue.

The narratives presented in this chapter are two examples of using narrative in organization studies. They are presented in fictive and semi-fiction form by different authors. The questions that remain are: How are these texts different? How are they the same? How does labelling one fiction and the other semi-fiction impact the interpretation of these genres of texts?

With a novelist like David Lodge, we know little about his ‘methodology’ of writing. The narrative is explicitly presented as a part of a fictional account of life. The intention is not to develop theory, although the author shows deep insight into areas such as the academic world and was, unsurprisingly, an academic himself. Whereas a semifiction account is as much about generating insight in the author as it is about presenting 
results in an imaginative way, the work of fiction is focused solely on the presentation of an entertaining and impactful narrative. At the same time, it is indistinguishable in form from the semi-fiction. It is the author's intentions, the attempt to bring fragments of the real into the narrative, and the context in which the narrative is produced that divides the two.

In contrast, in the excerpt of semi-fiction by Whiteman (2004), the author relied upon 18 months of ethnographic data as well as 'factual' texts like email exchanges, anonymous written reviews from the Academy of Management Journal , and actual conversations with living people, which was communicated in the methodology section preceding the semi-fictional account. These concrete elements formed the empirical basis from which she imaginatively explored in a creative form and were explained in her methods section.

The two types of texts are thus related to the extent that they use an imaginative narrative approach to cognitive processing (Bruner, 1986), and as such both demonstrate that organizing forms can be described (and analyzed) using more than logico-scientific style. However, aside from notable differences in quality (we can’t, unfortunately, all be David Lodge), the production of, and motivation behind, the representation style of fiction and semi-fiction texts may differ. That is, semi-fiction attempts to creatively build upon empirical data grounded in methodological rigour, while fiction makes no claims about data, method or rigour, although is arguably based upon experience (notwithstanding the author's typical note that this work is "entirely fictitious and not based upon any real people, dead or alive.”). 
We suggest that the labels themselves - of fiction and semi-fiction - may also influence the way the academic reader interprets or consumes the text. In particular, the label 'semi-fiction' signals that this is an imaginative narrative grounded in empirical experience and as such, differs significantly from traditionally accepted academic approaches to research. Semi-fiction attempts to have its cake and eat it too. In this way, semi-fiction acts as a type of Looking Glass, a narrative metaphor, which tests our attachment to entrenched academic traditions surrounding the production, representation and consumption of research. In contrast, a fictional label gives the reader a reflective 'way-out': it's not real so we don't have to take it seriously when we don’t want to. We acknowledge that fiction and semi-fiction remain 'loose' definitions or rough categories of narrative form that require academic experimentation, enactment and further refinement. Such academic sense-making will take time, yet we should not be daunted by this journey of inquiry. Indeed, as Geertz so sagely wrote nearly two decades ago in anthropology: "It's not clear just what "faction," imaginative writing about real people in real places at real times, exactly comes to beyond a clever coinage; but anthropology is going to have to find out if it is to continue as an intellectual force in contemporary culture” $(1988,141)$.

We end with a challenge: "If we admit that language has power over us, not only through what it says but also through what it is, we will be tolerant of literary experiment just as we are tolerant of scientific experiment” (Winterson, 1995: 76). Through fictional and semi-fictional play, a richer understanding of organizations and organizing forms may emerge. But we need more than tolerance; we need continued innovation in fact and fiction. 


\section{References}

Agar, M. 1990. Text and fieldwork: Exploring the excluded middle. Journal of Contemporary Ethnography, 19, 1, 73-88

Agar, M. 1995. Literary journalism as ethnography: Exploring the excluded middle. In Van Maanen, J. (Ed.), Representations in Ethnography (112-142). Thousand Oaks: Sage.

Astley, W. G. 1985. Administrative science as socially constructed truth. Administrative Science Quarterly, 30: 497-513.

Atwood, M. 1998. In search of Alias Grace: On writing Canadian historical fiction. The American Historical Review, 103 (5): 1503-1516.

Barry, D. 1996. Artful inquiry: A symbolic constructivist approach to social science research. Qualitative Inquiry, 2: 411-438.

Boje, D., Fitgibbons, D. E., \& Steingard, D. S. 1996. Storytelling at Administrative Science Quarterly: Warding off the postmodern barbarians. In Boje, D., Gephart. R. \& Joseph, T. (Eds.), Postmodern Management and Organization Theory. Newberry Park: Sage.

Bruner, J. 1986. Actual minds, possible worlds. Cambridge: Harvard University Press.

Capote, T. 1965. In cold blood: a true account of a multiple murder and its consequences. NY: Random House.

Carrithers, M. 1990. Is anthropology art or science? Current Anthropology, 31 (3), 263272.

Carroll, L. 1991. Through the looking glass. Retrieved 17-01-04 from http://www.literature.org/authors/carroll-lewis/through-the-lookingglass/index.html

Clifford, J. and G. E. Marcus. 1986. Writing culture: The poetics and politics of ethnography. Berkeley: University of California Press.

Currie, G. 1985. What is fiction? The Journal of Aesthetics and Art Criticism, 43 (4): 385-392.

Czarniawska, B. 1998. A narrative approach to organization studies. Thousand Oaks, CA: Sage.

Czarniawska-Joerges, B., \& Guillet de Monthoux, P. 1994. Good novels, better management: Reading organizational realities in fiction. Chur, Switzerland: Harwood. 
Dodgson, M, Gann, D. \& Salter, A. 2005 Think, play, do: Technology, innovation and organization. Oxford University Press: Oxford.

Geertz, C. 1988. Works and lives: The anthropologist as author. Stanford, CA: Stanford University Press.

Goffman, E. 1959. The presentation of self in everyday life. Anchor Books, New York.

Golden-Biddle, K., \& Locke, K. 1993. Appealing work: An investigation of how ethnographic texts convince. Organization Science, 4 (4), 595-616.

Gutkind, L. n.d. What's in this name - And what's not. Creative Nonfiction. Retrieved 17-01-04 from http://www.creativenonfiction.org/thejournal/articles/issue01/01editor.htm

Hammersley, M., \& Atkinson, P. 1995. Ethnography: Principles in practice, 2nd edition. London: Routledge.

Hansen, H., Barry, D., Boje, D., \& Hatch, M. J. 2006. Truth or consequences: An improvised collective story construction. Organization Studies.

Jeffcut, P. 1994. From interpretation to representation in organizational analysis: postmodernism, ethnography \& organizational symbolism. Organization Studies, 15 (2), 241-274.

Jermier, J. 1985. 'When the sleeper wakes': A short story extending themes in radical organization theory. Journal of Management Inquiry, 11 (2), 67-80.

Kennedy, E. and Lawton, L. (1992) Business ethics in fiction. Journal of Business Ethics, 11: 187-195.

Mailer, N. 1979. The executioner’s song. Boston : Little, Brown.

March, J. G. 2006. Poetry and the rhetoric of management: Easter 1916. Journal of Management Inquiry, 15: 70-72.

McLuhan, M. 1967. The medium is the message. New York: Random House.

O’Donnell, M. G. (1989) A historical note on the use of fiction to teach principles of economics. Journal of Economic Education, 20(3): 314-320.

Park, Y. 1982. The function of fiction. Philosophy and Phenomenological Research, 42 (3): 416-424.

Parker, M., Higgins, M., Lightfoot, G. ad Smith, W. (1999) Amazing tales: Organization studies as science fiction. Organization, 6(4): 579-590.

Phillips, N. 1995. Telling organizational tales: On the role of narrative fiction in the study of organizations. Organization studies, 16: 625-649. 
Phillips, N. and Zyglidopoulos, S. 1999. “Learning from Foundation: Asimov’s Psychohistory and the Limits of Organization Theory”, Organization, 6(4): 591608.

Richardson, L. 1994. Nine poems: Marriage and the family. Journal of Contemporary Ethnography, 23 (1), 3-13.

Rorty, R. 1991. Inquiry as recontextualization: An anti-dualist account of interpretation: In Hiley, D. R., Bohman, J. F., \& Shusterman, R. (Eds.), The interpretive turn: Philosophy, science, culture: 59-80. Ithaca, NY: Cornell University Press.

Rosen, M. 1985. Breakfast at Spiro’s: Dramaturgy and Dominance. Journal of Management, 11(2): 31-48.

Rosen, M. 1988. You asked for it: Christmas at the bosses expense. Journal of Management Studies, 25(5): 463-480.

Stablein, R. 1996. Data in organization studies. In Clegg, S,R., Hardy, C. \& Nord, W.R.,(Eds.) , Handbook of organization studies, (pp.509-525). Thousand Oaks: Sage.

Stein, G. 1922/1995. Geography and plays. Boston: The Four Seas Co.

Stein. G. 1933/2001. The autobiography of Alice B. Toklas. London: Penguin.

Taylor, S. 2000. Capitalist pigs at the Academy of Management. Journal of Management Inquiry, 9: 304-328.

Van Maanen, J. 1988. Tales of the field: On writing ethnography. Chicago: University of Chicago Press.

Van Maanen, J. (Ed.) 1995. Representation in ethnography. Thousand Oaks: Sage.

Whiteman, G. 2004. "Why are we talking inside? Reflecting on Traditional Ecological Knowledge (TEK) and management research”. Journal of Management Inquiry 13 (3), 261-277.

Winterson, J. 1995. Art objects: Essays on ecstasy and effrontery. Toronto: Knopf.

Wolfe, T. 1973. The new journalism. In Wolfe, T., \& Johnson, E. W. (Eds.), The new journalism (3-52). New York: Harper \& Row.

Wolcott, H. F. 1995. Making a study 'more’ ethnographic. In Van Maanen, J. (Ed.), Representation in Ethnography: 86-111. Thousand Oaks: Sage. 
Table 1: Fictional techniques to help build creative form. From Agar (1990).

\begin{tabular}{|l|l|}
\hline Fictional Techniques & \\
\hline The scenic method & $\begin{array}{l}\text { The author shows, rather than tells using rich, } \\
\text { sensory language to emphasize the immediacy of the } \\
\text { experience. }\end{array}$ \\
\hline Character development & $\begin{array}{l}\text { The story centers on a few characters both real and } \\
\text { compiled. The author uses 'internal monologues' to } \\
\text { express the characters' subjective point of view, and } \\
\text { also switches from different perspectives. }\end{array}$ \\
\hline Plot & $\begin{array}{l}\text { The author selects and arranges details to build } \\
\text { narrative tension and develop a convincing plot. }\end{array}$ \\
\hline Authorial presence & $\begin{array}{l}\text { The author is present, either in the story or as a voice } \\
\text { behind the story. }\end{array}$ \\
\hline
\end{tabular}




\section{Box 1: An Excerpt from David Lodge’s Small World}

Persse yawned and shifted his weight from one buttock to another in his seat at the back of the lecture-room. He could not see the faces of many of his colleagues, but as far as could be judged from their postures, most of them were as disengaged from the discourse as himself. Some were leaning back as far as their seats allowed, staring vacantly at the ceiling, others were slumped forwards onto the desks that separated each row, resting their chins on folded arms, and others again were sprawled sideways over two or three seats, with their legs crossed and arms dangling limply to the floor. In the third row a man was surreptitiously doing The Times crossword, and at least three people appeared to be asleep. Someone, a student presumably, had carved into the surface of the desk at which Persse sat, cutting deep into the wood with the force of a man driven to the limits of endurance, the word 'BORING'. Another had scratched the message, 'Swallow is a wanker'. Persse saw no reason to dissent from either of these judgements. (Lodge, 1984: 239-240). 
Box 2: Excerpt from Why are we talking inside?

Now Pip, can you please give us an example of TEK in action?” asked a committee member. "Help us understand what you're talking about."

"Sure," said Pip. "I can try. Let's see ... The use and value of TEK can best be described by story. In fact, Cree people use story to convey important information about their management approach. Unfortunately, such conversations can easily be marginalized by business executives and management scholars.”

Her supervisor grimaced. Pip continued,

“No, it's true. To illustrate this point, I want to offer a story of my own. Once when I was in James Bay, I was talking with my key informant, a Cree tallyman, who was telling me about his concerns regarding forestry. Freddy had a problem with the way the forestry company was replanting trees. He said to me, "After clearcutting, when they plant the trees ... it's theworst way to do it. Because when they plant a tree, I think it's going to taste different. Like when Porcupine eats it. ... It's going to be a different taste.”

Freddy felt that the porcupines needed greater variety than such replanting programs would allow.

(Whiteman, 2004: 7) 


\section{Publications in the ERIM Report Series Research* in Management}

\section{ERIM Research Program: "Organizing for Performance"}

\section{6}

IPRs, Technological Development, and Economic Development

Wilfred Dolfsma

ERS-2006-004-ORG

http://hdl.handle.net/1765/7301

Institution Building and Change in China

Barbara Krug and Hans Hendrischke

ERS-2006-008-ORG

http://hdl.handle.net/1765/7331

Rational Entrepreneurship in Local China: Exit Plus Voice for Preferential Tax Treatments

Ze Zhu, George W.J. Hendrikse and Barbara Krug

ERS-2006-010-ORG

http://hdl.handle.net/1765/7577

A Process Model of Locational Change in Entrepreneurial Firms: An Evolutionary Perspective Erik Stam

ERS-2006-014-ORG

http://hdl.handle.net/1765/7633

Starting Anew: Entrepreneurial Intentions and Realizations Subsequent to Business Closure Veronique Schutjens and Erik Stam

ERS-2006-015-ORG

$\underline{\text { http://hdl.handle.net/1765/7638 }}$

Agglomeration Economies and Entrepreneurship in the ICT Industry

Frank G. van Oort and Erik Stam

ERS-2006-016-ORG

http://hdl.handle.net/1765/7639

Renascent Entrepreneurship

Erik Stam, David Audretsch and Joris Meijaard

ERS-2006-017-ORG

http://hdl.handle.net/1765/7640

Social Life of Values

Slawomir Magala

ERS-2006-019-ORG

http://hdl.handle.net/1765/7645

Enterprise Ground Zero in China

ERS-2006-024-ORG

Barbara Krug

$\underline{\text { http://hdl.handle.net/1765/7853 }}$

Framing China: Transformation and Institutional Change

ERS-2006-025-ORG

Barbara Krug and Hans Hendrischke

http://hdl.handle.net/1765/7854 
Currents and Sub-currents in the River of Innovations - Explaining Innovativeness using New-Product Announcements Wilfred Dolfsma and Gerben van der Panne

ERS-2006-036-ORG

http://hdl.handle.net/1765/7943

Much Ado About Nothing: A conceptual critique of CSR

J. (Hans) van Oosterhout and Pursey P. M. A. R. Heugens

ERS-2006-040-ORG

http://hdl.handle.net/1765/7894

The Effect of Business Regulations on Nascent and Young Business Entrepreneurship

André van Stel, David J. Storey and A. Roy Thurik

ERS-2006-052-ORG

http://hdl.handle.net/1765/7996

Postmaterialism Influencing Total Entrepreneurial Activity across Nations

Lorraine Uhlaner and A. Roy Thurik

ERS-2006-062-ORG

http://hdl.handle.net/1765/8128

The Lag Structure of the Impact of Business Ownership on Economic Performance in OECD Countries

Martin Carree and A. Roy Thurik

ERS-2006-064-ORG

http://hdl.handle.net/1765/8126

Uncertainty Avoidance and the Rate of Business Ownership Across 21 OECD Countries, 1976-2004

Sander Wennekers, A. Roy Thurik, André van Stel and Niels Noorderhaven

ERS-2006-065-ORG

http://hdl.handle.net/1765/8125

Interacting Dimensions of Diversity: Cross-Categorization and the Functioning of Diverse Work Groups Astrid C. Homan, Daan van Knippenberg, Gerben A. Van Kleef and Carsten K. W. De Dreu ERS-2006-069-ORG

http://hdl.handle.net/1765/8500

Group Member Prototypicality and Intergroup Negotiation: How One's Standing in the Group Affects Negotiation Behaviour Gerben A. Van Kleef, Wolfgang Steinel, Daan van Knippenberg, Michael A. Hogg and Alicia Svensson

ERS-2006-070-ORG

http://hdl.handle.net/1765/8502

Bridging Faultlines by Valuing Diversity: Diversity Beliefs, Information Elaboration, and Performance in Diverse Work Groups Astrid C. Homan, Daan van Knippenberg, Gerben A. Van Kleef and Carsten K. W. De Dreu ERS-2006-071-ORG

http://hdl.handle.net/1765/8496

Affective Match: Leader Emotional Displays, Follower Positive Affect, and Follower Performance

Frederic Damen, Barbara van Knippenberg and Daan van Knippenberg

ERS-2006-072-ORG

http://hdl.handle.net/1765/8499

Leadership and Fairness: The State of the Art

Daan van Knippenberg, David De Cremer and Barbara van Knippenberg

ERS-2006-073-ORG

http://hdl.handle.net/1765/8501

The Role of Narrative Fiction and Semi-Fiction in Organizational Studies

Gail Whiteman and Nelson Phillips

ERS-2006-079-ORG 
* A complete overview of the ERIM Report Series Research in Management: https://ep.eur.nl/handle/1765/1

ERIM Research Programs:

LIS Business Processes, Logistics and Information Systems ORG Organizing for Performance

MKT Marketing

F\&A Finance and Accounting

STR Strategy and Entrepreneurship 